\title{
Association of Anger Expression-Out with NK Cell Counts in Colorectal Cancer Patients
}

\author{
Associação da Expressão da Raiva Para o Exterior a \\ Contagens de Células NK em Doentes com Cancro \\ Colorrectal
}

\author{
Estela KAKOO-BRIOSO $\square^{1}$, Luís COSTA², Sílvia OUAKININ¹ \\ Acta Med Port 2018 Mar;31(3):152-158 - https://doi.org/10.20344/amp.9573
}

\begin{abstract}
Introduction: There is growing evidence describing the relation between psychological factors and the progression of colorectal cancer. Several mechanisms have been proposed but the one showing more promising evidence relies on the modulation of the antitumoral immune response by psychological factors, particularly through natural killer cells. We aimed to study the relation between natural killer cell count and anxiety, depression and anger state, trait and expression in 54 pre-surgical colorectal cancer patients.

Material and Methods: We measured peripheral blood natural killer cell count and applied the State-Trait Anger Expression Inventory and the Hospital Anxiety and Depression Scale to 54 pre-surgical colorectal cancer patients. We used the Mann-Whitney U test and the Kruskal-Wallis test when appropriate to compare independent groups.

Results: Patients with higher Anger Expression-Out had lower natural killer cell numbers than patients with lower Anger ExpressionOut ( $p$ value $=0.008$ ). No relation was found between natural killer cell levels and Anger State, Anger Trait, or Anger Expression-In. No difference in natural killer cell count was found between patients with and without clinical anxiety or depression.

Discussion: These results suggest that, in colorectal cancer patients, natural killer cell counts are influenced by Anger Expression-Out, but not by clinical anxiety or depression.

Conclusion: The unregulated emotional expression might be a conditioning factor of innate immunity. Additional studies are needed to further investigate this relation and to ascertain the clinical impact of therapeutic interventions regarding emotional regulation on the anti-tumoral immune response.
\end{abstract}

Keywords: Anger; Colorectal Neoplasms; Depression; Killer Cells, Natural

\section{RESUMO}

Introdução: Existe crescente evidência da relação entre fatores psicológicos e progressão do cancro colorrectal. Vários mecanismos têm sido propostos porém o mais promissor baseia-se na modulação da resposta imune anti-tumoral pelos fatores psicológicos, particularmente através das células natural killer. Esta investigação teve como objetivo o estudo da relação entre as células natural killer e a ansiedade, a depressão e o estado, traço e expressão da raiva num grupo de 54 doentes pré-cirúrgicos com cancro colorrectal. Material e Métodos: Medimos a contagem periférica de células natural killer e aplicámos o Inventário de Estado-Traço de Raiva e a Escala Hospitalar de Ansiedade e Depressão a 54 doentes pré-cirúrgicos com cancro colorrectal. Usámos o teste U de Mann-Whitney e o teste Kruskal-Wallis para amostras independentes.

Resultados: Os doentes que apresentaram níveis mais elevados de Anger Expression-Out revelaram contagens inferiores de células natural killer ( $p$ value $=0,008$ ). Não encontrámos relação entre os níveis de células natural killer e o Anger State, Trait ou ExpressionIn. Não identificámos diferenças nas contagens de células natural killer entre doentes com e sem ansiedade clínica ou com e sem depressão clínica.

Discussão: Estes resultados sugerem que em doentes com cancro colorrectal a contagem de células natural killer é influenciada pela Anger Expression-Out, mas não pela depressão ou ansiedade clínica.

Conclusão: A desregulação da expressão emocional pode ser um factor condicionante da imunidade inata. São necessários estudos adicionais para investigar mais aprofundadamente esta relação e para estabelecer o impacto clínico na resposta imune anti-tumoral das intervenções terapêuticas dirigidas à regulação emocional.

Palavras-chave: Células Matadoras Naturais; Depressão; Ira; Neoplasias Colorrectais

\section{INTRODUCTION}

Colorectal cancer is the third most common cancer in men (746 000 cases in 2012) and the second in women (614 000 cases in 2012) worldwide, having a high mortality rate and constituting an important burden in healthcare. ${ }^{1}$

Colorectal cancer is frequently associated with anxiety $(2.91 \%)$ and depression $(54.37 \%)$ disorders, ${ }^{2-4}$ both considered leading specific causes of years lived with disability (YLDs) in 2010. ${ }^{5}$ Anxiety and depression strongly and independently affect health-related quality of life. ${ }^{6,7}$ Depression alone is present in $9.3 \%-23.0 \%$ of patients with chronic physical diseases and carries an important impact on individuals. ${ }^{8}$ In fact, depression affects health scores more than other chronic conditions, ${ }^{8}$ besides increasing functional disability, lost productivity and health resource utilization in patients with chronic medical conditions. ${ }^{9}$ Depressive symptoms have also been associated with a

1. Clínica Universitária de Psiquiatria e Psicologia Médica. Faculdade de Medicina. Universidade de Lisboa. Lisboa. Portugal.

2. Serviço de Oncologia Médica. Hospital de Santa Maria. Lisboa. Portugal.

$\square$ Autor correspondente: Estela Kakoo-Brioso. estela.kakoo@gmail.com

Recebido: 17 de agosto de 2017 - Aceite: 19 de fevereiro de 2018 | Copyright @ Ordem dos Médicos 2018 
twofold-increased risk for all-cause mortality. ${ }^{10}$ In a study conducted with 2924 cancer patients, $7.8 \%$ reported having thoughts that they would be better off dead or thoughts of hurting themselves. ${ }^{11}$ When considering colorectal cancer alone, almost twice the prevalence $(14.3 \%)$ of patients with persistent suicidal thoughts was found. ${ }^{12}$

Anger is a common reaction among patients with cancer but when maladaptive, anger may be associated with poor functioning levels and have impact on both symptoms (e.g. worsening pain) and outcomes of disorders such as coronary heart disease. ${ }^{13-15}$ Also, emotional repression and negative emotions have been associated in previous studies with changes in immune responses and cancer progression. ${ }^{16}$

We now know that psychological morbidity can have an important impact on both quality of life and major clinical outcomes in cancer patients. ${ }^{17}$

Prognostic factors able to accurately predict malignant diseases outcome have been widely studied but it has been difficult to ascertain which factors weight more in cancer progression. In colorectal cancer, prognosis is mostly based upon the TNM classification ${ }^{18}$ and tumor cell differentiation yet, in recent studies, tumor-infiltrated lymphocytes, particularly $\mathrm{CD}^{+}$and natural killer (NK) cells, have been shown to constitute a better indicator of tumor recurrence than the American Joint Committee on Cancer (AJCC) / International Union Against Cancer (UICC) - TNM staging. ${ }^{19-21}$

Indeed, NK cells are able to efficiently kill transformed cells, and thus represent one of the most important immune cell subset in host anti-tumoral response. ${ }^{22}$ Colorectal cancer patients exhibiting higher NK cell counts tend to have longer overall survival and, when assessed by multivariate analysis, NK cell counts are found to constitute an independent prognostic factor of overall survival. ${ }^{20,23}$ In breast cancer patients NK cell activity predicts disease progression and recurrence. ${ }^{24,25}$

Moreover, psychological factors have been demonstrated to impact the immune system and, in particular, to impact NK cells in cancer patients. ${ }^{26,27}$ Steel et al have shown an association between depressive symptoms, decreased NK cell numbers and decreased survival in hepatobiliar carcinoma patients. ${ }^{28}$ Also, social support and distress affect cellular immune response both in peripheral blood and at the tumor level. ${ }^{29}$ The impact of anxiety, dysphoria and anger on the immune system is not only reflected by a decreased cell number but also by an impaired NK cell activity and response to cytokines. ${ }^{30-33}$ Similar results were found in breast cancer patients with poor adjustment and lack of social support. ${ }^{34}$

Psychological factors such as depression not only impair immune parameters as are in fact linked to shortened survival in cancer patients. Loberiza et al found that patients experiencing a depressive syndrome after hematopoietic stem-cell transplantation tend to have decreased survival (at least from 6 to 12 months) when compared to nondepressed individuals. ${ }^{35}$ Similarly, depression appears to constitute an important prognostic indicator in breast cancer patients as is evidenced by a higher risk of mortality in patients with this condition. ${ }^{36}$

Although several psychological factors have been implicated in the modulation of the immune system in cancer patients, no work exists, to the extent of our knowledge, on the impact of anger on NK cells in colorectal cancer. Furthermore, no group has studied the relation of anxiety and depression with NK cells in the Portuguese population.

Our aim was to investigate whether anxiety, depression, or anger state, trait, and expression had impact on the innate immunity of colorectal cancer patients undergoing surgery, particularly through modulation of the NK cell population. We hypothesized that both clinical anxiety and depression would negatively influence the innate immunity by diminishing the number of circulating NK cells. Also, we postulated that specific patterns of anger expression would have impact on the immune state. Particularly, we theorized that the suppression of angry feelings would have a negative impact on the number of NK cells.

Therefore, we studied anger state, trait, and expression, as well as anxiety and depression, and NK cell count in 54 Portuguese pre-surgical colorectal cancer patients.

\section{MATERIAL AND METHODS Design}

A cross-sectional design was applied and data was collected at Santa Maria Hospital, Lisbon, Portugal, from January 2012 to May 2014.

\section{Participants}

All participants were colorectal cancer patients undergoing elective surgery and were evaluated for this study the day before the procedure. The patients were informed of the objectives of the study, were assured of their anonymity and confidentiality, and signed an informed consent. The Hospital ethical committee revised and approved this study.

Inclusion criteria were as follows: a clinical diagnosis of colorectal cancer and admission to a surgical ward for elective surgery. All patients who met the inclusion criteria during the aforementioned period were further evaluated for the following exclusion criteria: age below 40 (in order to exclude inherited genetic conditions), unawareness of colorectal cancer diagnosis, inability to comprehend and fulfill what is required and existence of known metastases at the time of surgery. To minimize confounding factors, patients who underwent neo-adjuvant chemotherapy or radiotherapy, or who had high probability of surgical treatment with subsequent colostomy were also excluded from the study.

\section{Instruments}

All patients answered a social, demographic and clinical questionnaire and were applied the State-Trait Anger Expression Inventory ${ }^{37,38}$ and the Hospital Anxiety and Depression Scale..$^{39,40}$ Both instruments are translated to 
Portuguese and validated to the Portuguese population. ${ }^{38,40}$

The State-Trait Anger Expression Inventory (STAXI) is a 44-item inventory, divided into six scales and two subscales, which assess anger experience, expression and control. ${ }^{37,38}$ STAXI is comprised of 1) State Anger (S-Anger), which measures the intensity of anger feelings at a giving time; 2) Trait Anger (T-Anger) which measures the differences between individuals in the frequency and disposition for experiencing anger states, including two subscales: a) Angry-temperament (T-Anger/T), which evaluates the general propensity for experiencing and expressing anger feelings with no specific provocation; and b) Angry Reaction (T-Anger/R) which gauges the differences in anger expression between individuals when criticized or unfairly treated; 3) Anger-in (AX/In), which assesses the frequency with which anger feelings are repressed; 4) Anger-out (AX/ Out), which assesses how frequently anger is directed towards other people and objects; 5) Anger Control (AX/ Con), which assesses the frequency with which the individual tries to control the expression of his/her anger; and 6) Anger Expression (AX/EX), which indicates the frequency with which anger is expressed, regardless of how it is expressed. On each of the described scales patients were divided into two groups. Patients with scores above the mean value of a previously described general medical and surgical population ${ }^{37}$ were categorized into 'high' while patients with scores below the mean were classified as 'low'.

The Hospital Anxiety and Depression Scale (HADS) is a 14-item questionnaire, of which seven assess anxiety (HADS-A) and seven assess depression (HADS-D). Each item is scored from 0 to 3 , to a maximum of $21.39,40$ Scores between 0 and 7 are considered non-clinical for both depression and anxiety. Scores above 7 in HADS-D or HADS-A represent clinical depression or anxiety respectively, which can be further categorized into mild (8 - 10), moderate (11 - 14) and severe (15 - 21). Cronbach's alpha for the Portuguese version was 0.76 for anxiety and 0.81 for depression $(n=1322) .{ }^{39,40}$

\section{NK cell number}

Peripheral blood natural killer (CD3- CD56 ${ }^{+}$) cell counts were obtained by flow cytometry using FACSCalibur ${ }^{\mathrm{TM}}$ (Becton Dickinson Biosciences, CA, USA). We used the Anti-CD3 FITC (Becton Dickinson Biosciences, CA, USA) and Anti-CD56 PE (Becton Dickinson Biosciences, CA, USA).

\section{Statistical analysis}

Statistical analysis was performed using IBM $^{\circledR}$ SPSS $^{\circledR}$ Statistics version 22.

Since for each hypothesis test the assumption of both normality (Shapiro-Wilk test) and homogeneity of variance (Levene's test) could not be met, the non-parametric MannWhitney $U$ test was used to compare differences between two independent groups, whereas the non-parametric Kruskal-Wallis test was used to compare differences among three or more independent groups. $p$ values $\leq 0.05$ were considered statistically significant. All tests were two-tailed.

\section{RESULTS}

\section{Demographics and immunological results}

We studied 54 patients diagnosed with colorectal cancer admitted for surgery. Sociodemographic data are represented in Table 1. Of the 54 patients, two refused to be submitted to venipuncture and therefore lack NK cell counts. Across the 52 patients, NK cell numbers ranged from $0.03 \times 10^{9} / \mathrm{L}$ to $0.82 \times 10^{9} / \mathrm{L}$, with a mean value of 0.283 $\times 10^{9} / \mathrm{L}$ and a standard deviation of $0.182 \times 10^{9} / \mathrm{L}$.

\section{Anger state, trait, and expression}

Anger Expression-Out appears to significantly influence NK cell count. Patients who frequently direct anger outwards

Table 1 - Sociodemographic characteristics of sample

\begin{tabular}{lcc}
\hline & Mean & SD \\
\hline Age (years) & 66.59 & 10.35 \\
Education (years) & 8.41 & 5.3 \\
\hline \multicolumn{1}{c}{$\mathbf{n}$} & $\%$ \\
\hline Gender & & \\
$\quad$ Male & 32 & 59.3 \\
$\quad$ Female & 22 & 40.7 \\
Marital status & & \\
$\quad$ Married & 37 & 68.5 \\
$\quad$ Single, never married & 3 & 5.6 \\
$\quad$ Separated/divorced & 3 & 5.6 \\
Widowed & 11 & 20.4
\end{tabular}

Children

$\begin{array}{lcc}0 & 6 & 11.1 \\ 1 & 13 & 24.1 \\ 2 & 26 & 48.1 \\ 3 & 5 & 9.3 \\ 4 & 3 & 5.6 \\ 5 & 1 & 1.9\end{array}$

Employment

$\begin{array}{lcc}\text { Retired } & 29 & 53.7 \\ \text { Employed } & 14 & 25.9 \\ \text { Housewife } & 9 & 16.7 \\ \text { Unemployed } & 2 & 3.7\end{array}$

Primary Cancer Diagnosis

Colon cancer $\quad 49 \quad 90.7$

Rectal cancer $\quad 5 \quad 9.3$

\section{AJCC/UICC-TNM Staging}

$\begin{array}{lcc}\text { Stage 0 } & 4 & 7.4 \\ \text { Stage I } & 10 & 18.5 \\ \text { Stage II } & 15 & 27.8 \\ \text { Stage III } & 24 & 44.4 \\ \text { Stage IV } & 1 & 1.9\end{array}$


had lower NK cell numbers than patients with lower Anger Expression-Out ( $p$ value $=0.008)$ (Table 2). No relation was found between NK cell levels and Anger State, Anger Trait, Anger Trait Temperament, Anger Trait Reaction, or Anger Expression-In.

\section{Anxiety and depression}

Among the 54 patients, anxiety levels ranged from 0 to 17 , with a mean value of 6.93 (Table 3 ). Less than half of the patients (23 out of 54 ) had clinical anxiety, which was distributed through mild (20.4\%), moderate (11.1\%), and severe $(11.1 \%)$ categories. A total of $57.4 \%$ had non-clinical anxiety. As far as depression is concerned, the vast majority (42 out of 54) had non-clinical levels, whereas $22.3 \%$ had mild (3 in 12), moderate (5 in 12), or severe (4 in 12) depression. Mean value of depression was 5.5 (range 0 20).

No difference in NK cell count was found between patients with and without clinical anxiety, even when clinical anxiety was divided according to severity. Regarding depression, differences among patients with clinical and non-clinical levels were non-significant. Accordingly, differences among severity groups revealed no significance.

\section{DISCUSSION}

Our results show that a quarter of colorectal cancer patients (13 in 52) had a temperament characterized by a higher propensity to experience anger states than the general medical and surgical population. Likewise, $26.9 \%$ frequently expressed those emotions towards others. These results suggest a possible impairment in the emotional regulation of these patients. Furthermore, this feature appears to play a deleterious role in immune cancer surveillance, as evidenced by the significant lower NK cell count found in patients with a more outward expression of anger (Anger Expression-Out), as well as in patients with higher anger trait and temperament, although the significance could not be reached in the latter, possibly due to the small sample size.

Interestingly, NK cells did not differ according to anger state, suggesting that the psychological immune regulation appears to be achieved in greater extent by intrinsic features of the patients instead of resulting from a transient psychological state. Besides the significance of intrinsic features in immune regulation, it is apparent that the propensity for experiencing anger emotions (Anger Trait Temperament) is important per se in modulating NK cell numbers, independently of the stimuli triggering those same anger states, seeing as the Anger Trait Reaction had no influence in NK cells. Contrarily to our initial hypothesis, we could not find a relation between Anger Expression-In and the number of NK cells. These results are dissonant with other published work, ${ }^{16}$ triggering the need for more studies to establish the true impact of repressing angry feelings.

These are novel results since there are very few studies on the relation between anger and NK cells and their results are mainly discrepant ${ }^{41,42}$ and no work exists with colorectal cancer patients, which makes the comparison with our results unreasonable.

Table 2 - NK cell distribution across STAXI categories

\begin{tabular}{|c|c|c|c|c|}
\hline & \multicolumn{2}{|c|}{ NK cells (x10\%/L) } & \multirow[b]{2}{*}{ n (\%) } & \multirow[b]{2}{*}{$p$ value } \\
\hline & Mean & SD & & \\
\hline \multicolumn{5}{|l|}{ STAXI } \\
\hline Anger State & & & & 0.584 \\
\hline Low & 0.278 & 0.183 & $43(82.7)$ & \\
\hline High & 0.306 & 0.185 & $9(17.3)$ & \\
\hline Anger Trait & & & & 0.070 \\
\hline Low & 0.294 & 0.185 & $48(92.3)$ & \\
\hline High & 0.147 & 0.057 & $4(7.7)$ & \\
\hline Anger Trait Temperament & & & & 0.081 \\
\hline Low & 0.309 & 0.195 & $39(75.0)$ & \\
\hline High & 0.206 & 0.110 & $13(25.0)$ & \\
\hline Anger Trait Reaction & & & & 0.812 \\
\hline Low & 0.288 & 0.189 & $46(88.5)$ & \\
\hline High & 0.241 & 0.121 & $6(11.5)$ & \\
\hline Anger Expression-In & & & & 0.859 \\
\hline Low & 0.273 & 0.142 & $21(40.4)$ & \\
\hline High & 0.290 & 0.207 & $31(59.6)$ & \\
\hline Anger Expression-Out & & & & $0.008^{*}$ \\
\hline Low & 0.312 & 0.176 & $38(73.1)$ & \\
\hline High & 0.204 & 0.180 & $14(26.9)$ & \\
\hline
\end{tabular}

${ }^{*} p$ value $\leq 0.05$ (significant) 
Table 3 - NK cell distribution across HADS categories

\begin{tabular}{|c|c|c|c|}
\hline HADS & $\mathbf{n}$ & Mean & SD \\
\hline Anxiety & 54 & 6.93 & 4.69 \\
\hline \multirow[t]{3}{*}{ Depression } & 54 & 5.5 & 4.63 \\
\hline & \multicolumn{3}{|c|}{ NK cells $\left(\times 10^{9} / L\right)$} \\
\hline & n (\%) & Mean & SD \\
\hline Anxiety & $52(100)$ & & \\
\hline Non-Clinical & $30(57.7)$ & 0.318 & 0.207 \\
\hline Clinical & $22(42.3)$ & 0.235 & 0.131 \\
\hline Mild & $11(21.2)$ & 0.201 & 0.113 \\
\hline Moderate & $6(11.5)$ & 0.217 & 0.098 \\
\hline Severe & $5(9.6)$ & 0.332 & 0.175 \\
\hline \multicolumn{4}{|l|}{$p$-value } \\
\hline Clinical vs Non-Clinical & & 0.266 & \\
\hline Non-Clinical vs Mild vs Moderate vs Severe & & 0.354 & \\
\hline Depression & $52(100)$ & & \\
\hline Non-Clinical & $40(76.9)$ & 0.283 & 0.189 \\
\hline Clinical & $12(23.1)$ & 0.283 & 0.164 \\
\hline Mild & $3(5.8)$ & 0.356 & 0.242 \\
\hline Moderate & $5(9.6)$ & 0.268 & 0.183 \\
\hline Severe & $4(7.7)$ & 0.246 & 0.085 \\
\hline \multicolumn{4}{|l|}{$p$-value } \\
\hline Clinical vs Non-Clinical & & 0.745 & \\
\hline Non-Clinical vs Mild vs Moderate vs Severe & & 0.896 & \\
\hline
\end{tabular}

Surprisingly, we did not find any relation between depression levels and NK cell count, which is contrary to other works. ${ }^{26-28}$ This difference might be the result of lack of statistical power due to the small sample size, in particular due to the large difference between the number of patients with and without clinical depression. Moreover, other authors used different scales to measure depression, which might have resulted in a different selection of depressed and nondepressed patients. Further work is needed to assess if this discrepancy constitutes a true difference in populations or is merely the result of different methods.

We did not find any difference in NK cells in patients with different levels of anxiety. However, our study measured only NK cell number. Tashiro et al described a positive correlation between trait anxiety and NK cell activity, ${ }^{33}$ which might suggest that anxiety mediates immune function in a qualitative rather than in a quantitative way. Further investigation is needed since no other studies, to the extent of our knowledge, have investigated the influence of anxiety on NK cell counts in colorectal cancer patients.

Although we found an important association between anger expression-out and NK cell counts, the crosssectional design and the sample size of this research do not allow us to establish causality. Besides, we did not study how this association changed with time or the possible impact of therapeutic interventions. We also could not evaluate the impact on prognosis or major outcomes due to the observational nature of our design.
It is also important to note that only one subset of the immune system (NK cells) was measured and that the immune response in cancer patients is a more complex process. It would be relevant to replicate this study with the inclusion of more subsets of circulating lymphocytes and a qualitative analysis of cellular function. Additionally, evaluating the local immune response (tumor-infiltrating lymphocytes) might cast an additional light in this complex interaction.

Despite these limitations and the different results when compared to other research, this study is an important foundation for further prospective studies. Our work highlighted that the unregulated emotional expression might potentially be associated with a higher risk of immune imbalance and should thus be sought and therapeutic guidance should be offered. The growing number of research stressing the importance of immunity in cancer allows us to hypothesize that intervention aimed at psychological morbidity might not only enhance the quality of life of cancer patients but also their disease prognosis.

\section{CONCLUSION}

Our results suggest that Anger Expression-Out influences NK cell count in colorectal cancer patients. Additional studies are needed to further investigate this relation and to ascertain the clinical impact of therapeutic interventions regarding emotional regulation on the antitumoural immune response. 


\section{PROTECTION OF HUMANS AND ANIMALS}

The authors declare that the procedures were followed according to the regulations established by the Clinical Research and Ethics Committee and to the Helsinki Declaration of the World Medical Association.

\section{DATA CONFIDENTIALITY}

The authors declare having followed the protocols in use at their working center regarding patients' data publication. Informed consent was duly obtained from the patient.

\section{REFERENCES}

1. Fact Sheets by Cancer. International Agency for Research on Cancer; c2018. [Accessed 2018 Feb 15]. Available at: http://globocan.iarc.fr/ Pages/fact_sheets_cancer.aspx?cancer=colorectal.

2. Hong JS, Tian J. Prevalence of anxiety and depression and their risk factors in Chinese cancer patients. Support Care Cancer. 2013;22:4539.

3. Walker J, Hansen $\mathrm{CH}$, Martin P, Symeonides S, Ramessur R, Murray $\mathrm{G}$, et al. Prevalence, associations, and adequacy of treatment of major depression in patients with cancer: A cross-sectional analysis of routinely collected clinical data. Lancet Psychiatry. 2014;1:343-50.

4. Zhang AY, Cooper GS. Recognition of depression and anxiety among elderly colorectal cancer patients. Nurs Res Pract. 2010;1-8.

5. Vos T, Flaxman AD, Naghavi M, Lozano R, Michaud C, Ezzati M, et al. Years lived with disability (YLDs) for 1160 sequelae of 289 diseases and injuries 1990-2010: A systematic analysis for the Global Burden of Disease Study 2010. Lancet. 2012;380:2163-96.

6. Brown LF, Kroenke K, Theobald DE, Wu J, Tu W. The association of depression and anxiety with health-related quality of life in cancer patients with depression and/or pain. Psychooncology. 2009;19:734-41.

7. Graça Pereira M, Figueiredo AP, Fincham FD. Anxiety, depression, traumatic stress and quality of life in colorectal cancer after different treatments: a study with Portuguese patients and their partners. Eur J Oncol Nurs. 2012;16:227-32.

8. Moussavi S, Chatterji S, Verdes E, Tandon A, Patel V, Ustun B. Depression, chronic diseases, and decrements in health: results from the World Health Surveys. Lancet. 2007;370:851-8.

9. Egede LE. Major depression in individuals with chronic medical disorders: Prevalence, correlates and association with health resource utilization, lost productivity and functional disability. Gen Hosp Psychiatry. 2007;29:409-16.

10. Mols F, Husson O, Roukema J, Poll-Franse LV. Depressive symptoms are a risk factor for all-cause mortality: Results from a prospective population-based study among 3,080 cancer survivors from the PROFILES registry. J Cancer Surviv. 2013;7:484-92.

11. Walker J, Waters RA, Murray G, Swanson H, Hibberd CJ, Rush RW. Better off dead: suicidal thoughts in cancer patients. J Clin Oncol. 2008;26:4725-30.

12. Shaheen Al Ahwal MS, Zaben FA, Khalifa DA, Sehlo MG, Ahmad RG, Koenig HG. Depression in patients with colorectal cancer in Saudi Arabia. Psychooncology. 2014;24:1043-50.

13. Gerhart JI, Sanchez Varela V, Burns JW. Brief training on patient anger increases oncology oroviders' self-efficacy in communicating with angry patients. J Pain Symptom Manage. 2017;54:355-60.e2.

14. Burns JW, Holly A, Quartana P, Wolff B, Gray E, Bruehl S. Trait anger management style moderates effects of actual ("state") anger regulation on symptom-specific reactivity and recovery among chronic low back pain patients. Psychosom Med. 2008;70:898-905.

15. Chida $Y$, Steptoe A. The association of anger and hostility with future coronary heart disease: A meta-analytic review of prospective evidence. J Am Coll Cardiol. 2009;53:936-46.

16. Bruno A, Pandolfo G, Scimeca G, Leonardi V, Cedro C, Racchiusa S. Anger in health, benign breast disease and breast cancer: a prospective case-control study. In Vivo. 2014;28:973-7.

17. Brown KW, Levy AR, Rosberger Z, Edgar L. Psychological distress and cancer survival: a follow-up 10 years after diagnosis. Psychosom Med. 2003;65:636-43.

18. Sobin LH, Gospodarowicz M, Wittekind C, editors. TNM classification of malignant tumours. $7^{\text {th }}$ ed. Hoboken: Wiley-Blackwell; 2010.

19. Mlecnik B, Tosolini M, Kirilovsky A, Berger A, Bindea G, Meatchi T, et al. Histopathologic-based prognostic factors of colorectal cancers are

\section{CONFLICTS OF INTEREST}

The authors declare no conflict of interests.

\section{FUNDING SOURCES}

This research was supported by a PhD fellowship grant from Fundação para a Ciência e a Tecnologia (FCT Grant No. SFRH / BD / 48167 / 2008).

associated with the state of the local ilmmune reaction. J Clin Oncol. 2011;29:610-8.

20. Milasiene V, Stratilatovas E, Norkiene V. The importance of T-lymphocyte subsets on overall survival of colorectal and gastric cancer patients. Medicina. 2007;43:548-54.

21. Deschoolmeester V, Baay M, Van Marck E, Weyler J, Vermeulen P, Lardon $F$, et al. Tumor infiltrating lymphocytes: an intriguing player in the survival of colorectal cancer patients. BMC Immunol. 2010;11-9.

22. Lança T, Silva-Santos B. The split nature of tumor-infiltrating leukocytes: Implications for cancer surveillance and immunotherapy. Oncoimmunology. 2012;1:717-25.

23. Qiu H, Xiao-Jun W, Zhi-Wei Z, Gong C, Guo-Qiang W, Li-Yi Z, et al. The prognostic significance of peripheral T-lymphocyte subsets and natural killer cells in patients with colorectal cancer. Hepatogastroenterology. 2009;56:1310-5.

24. Levy S, Herberman RB, Maluish AM, Schlien B, Lippman M. Prognostic risk assessment in primary breast cancer by behavioral and immunological parameters. Health Psychol. 1985;4:99-113.

25. Levy S, Herberman RB, Lippman M, d'Angelo T, Lee J. Immunological and psychosocial predictors of disease recurrence in patients with earlystage breast cancer. Behav Med. 1991;17:67-75.

26. Sachs G, Rasoul-Rockenschaub S, Aschauer H, Spiess K, Göber I, Staffen A, et al. Lytic effector cell activity and major depressive disorder in patients with breast cancer: A prospective study. J Neuroimmunol. 1995;59:83-9.

27. Orsi AJ, McCorkle R, Tax AW, Barsevick A. The relationship between depressive symptoms and immune status phenotypes in patients undergoing surgery for colorectal cancer. Psychooncology. 1996;5:311 9.

28. Steel JL, Geller DA, Gamblin TC, Olek MC, Carr BI. Depression, immunity, and survival in patients with hepatobiliary carcinoma. J Clin Oncol. 2007;25:2397-405.

29. Lutgendorf SK, Sood AK, Anderson B, McGinn S, Maiseri H, Dao M, et al. Social support, psychological distress, and natural killer cell activity in ovarian cancer. J Clin Oncol. 2005;23:7105-13.

30. Ben-Eliyahu S, Shakhar G, Page GG, Stefanski V, Shakhar K Suppression of NK cell activity and of resistance to metastasis by stress: A role for adrenal catecholamines and beta-adrenoceptors. Neuroimmunomodulation. 2000;8:154-64.

31. Irwin M. Psychoneuroimmunology of depression: clinical implications Brain Behav Immun. 2002;16:1-16.

32. Fawzy FI, Kemeny ME, Fawzy NW, Elashoff R, Morton D, Cousins $\mathrm{N}$, et al. A structured psychiatric intervention for cancer patients: II. Changes over time in immunological measures. Arch Gen Psychiatry. 1990;47:729-35.

33. Tashiro M, Itoh M, Kubota K, Kumano H, Masud MM, Moser E, et al. Relationship between trait anxiety, brain activity and natural killer cell activity in cancer patients: a preliminary PET study. Psychooncology. 2001;10:541-6.

34. Levy S, Herberman RB, Lippman M, d'Angelo T. Correlation of stress factors with sustained depression of natural killer cell activity and predicted prognosis in patients with breast cancer. J Clin Oncol. 1987;5:348-53.

35. Loberiza FR, Rizzo JD, Bredeson CN, Antin JH, Horowitz MM, Weeks $\mathrm{JC}$, et al. Association of depressive syndrome and early deaths among patients after stem-cell transplantation for malignant diseases. J Clin Oncol. 2002;20:2118-26.

36. Hjerl K, Andersen EW, Keiding N, Mouridsen HT, Mortensen PB, Jørgensen T. Depression as a prognostic for breast cancer mortality. Psychosomatics. 2003;44:24-30. 
37. Spielberger CD. State-trait anger expression inventory: professional manual. Odessa: Psychological Assessment Resources; 1988.

38. Silva DR, Campos R, Prazeres N. O inventário de estado-traço de raiva (STAXI) e a sua adaptação para a população portuguesa. Rev Port Psicol. 1999;34:55-81.

39. Zigmond AS, Snaith RP. The hospital anxiety and depression scale. Acta Psychiatr Scand. 1983;67:361-70.

40. Pais-Ribeiro J, Silva I, Ferreira T, Martins A, Meneses R, Baltar M. Validation study of a Portuguese version of the hospital anxiety and depression scale. Psychol Health Med. 2007;12:225-35.

41. Farnam A, Majidi J, Nourazar SG, Ghojazadeh M, Movassaghpour A Zolbanin SM. Effect of anger patterns and depression on serum IgA and NK cell frequency. Iran J Immunol. 2016;13:37-44.

42. Penedo FJ, Dahn JR, Kinsinger D, Antoni MH, Molton I, Gonzalez JS Anger suppression mediates the relationship between optimism and natural killer cell cytotoxicity in men treated for localized prostate cancer. J Psychosom Res. 2006;60:423-7. 